\title{
Clinical evaluation of a self-adhering flowable composite as occlusal restorative material in primary molars: one-year results
}

\section{Purpose}

The aim of this study was to evaluate and compare the 1 year clinical performances of a self-adhering flowable composite and a commercially available self-etch adhesive/composite system in occlusal restorations of primary second molars.

\section{Patients and Methods}

Thirty-one patients ( 10 male, 21 female) were recruited into the study. A total of 62 occlusal cavities were restored with either a universal composite or a self-adhering flowable composite according to manufacturers' instructions. The restorations were clinically evaluated 1 month after placement as baseline, and after 3,6 months and 1 year post-operatively using modified USPHS criteria by two operators.

\section{Results}

Lack of retention was not observed in any of the restorations. With respect to color match, marginal adaptation, secondary caries and surface texture, no significant differences were found between two restorative materials tested after 1 year. None of the restorations had marginal discoloration and anatomic form loss on the 1 year follow-up. Restorations did not exhibit post-operative sensitivity at any evaluation period.

\section{Conclusion}

The clinical assessment of self-adhering flowable composite exhibited good clinical results with predominating alpha scores after 1 year. Advantage of the application convenience for children is promising for self-adhered flowable composite materials in pediatric use.

Keywords: Self-adhesive; restorative; primary; children; dentition; caries

\section{Introduction}

Dental caries among children continues to be a major public health problem throughout the world. Preservation of primary teeth is important for the maintenance of arch length, maintenance and improvement of physical appearance, maintenance of healthy oral environment, prevention and relief of pain, functions of chewing and speech (1).

Composite resins are esthetic restorative materials used for anterior and posterior teeth. There are variety of resin products on the market with each having different physical properties and handling characteristics based upon their composition for use in primary dentition. Adhesive systems allow bonding of composite resins to primary and permanent teeth. Practical and time saving restorative materials are convenient for the pediatric practices. Research advancements have mainly aimed on the simplification of the technique while enhancing retention of restorations, minimizing microleakage and reducing sensitivity (2). A further advancement in adhesive dentistry is represented by the recent introduction of a so-called "self-adhering composite resin" (compobond), which combines an all-inone bonding system and a flowable composite (2). Improving marginal

\author{
Buse Ayse Serin ${ }^{1}$ (D), \\ Iffet Yazicioglu' ${ }^{1}$ (D), \\ Ceren Deveci ${ }^{1}$ (D), \\ Muharrem Cem Dogan ${ }^{1}$
}

ORCID IDs of the authors: B.A.S. 0000-0001-6779-8166; I.Y. 0000-0001-7214-0764 C.D. $0000-0002-3874-1176$ M.C.D. 000-0001-6393-9208

'Department of Pediatric Dentistry, Faculty of Dentistry, Cukurova University, Adana, Turkey Corresponding Author: Iffet Yazicioglu E-mail: iffet_yazicioglu@yahoo.com Received: 20 February 2019 Revised: 3 May 2019 Accepted: 27 June 2019 DOI: $10.26650 /$ eor.20190025 
adaptation of restorations in relation to their rheological properties is also targeted (2-7). Flowable composites, as compared with conventional hybrid composites, exhibit lower mechanical properties due to their reduced filler content $(8,9)$. However for the restoration of cavities in high load-bearing areas, the use of flowable composites is recommended only for cavity lining (10). Conversely, in the restoration of smallsized cavities, as most of the occlusal forces are resisted by the residual tooth structure, the use of flowable composites as stand-alone materials has been recommended (11). Traditional flowable composite resins require a separate bonding system but this self-adhering flowable composite resin eliminates the need for a separate adhesive application. This presents a practical working condition of treatment for children.

The purpose of this study was to evaluate a self-adhering flowable composite and compare its 12 months clinical performances with a commercially available self-etch adhesive / composite system in occlusal restorations of primary molars. The null hypothesis tested in this study is that no difference could be found between the clinical performances of the composite materials.

\section{Patients and Methods}

\section{Study design and ethical approval}

This single blind randomized clinical trial was approved by Ethics Committee of the University of Cukurova after written informed consent was obtained from the parents or guardians of all children in the study. The study protocol and informed consent document was approved by the Çukurova University Ethical Committee (April 4, 2014, study approval number 30), a subdivision of Turkish Ministry of Health, works full accordance with the World Medical Association Declaration of Helsinki. Split mouth design was conducted according to the Consolidated Standards of Reporting Trials (CONSORT) (12).
From March 2012 to September 2013, all children scheduled to start the dental treatment in pediatric dental clinic were screened by one instructor and enrolled in this study. The inclusion criteria were; being mentally and physically healthy, having at least two occlusal primary caries lesions on primary molars in a split-mouth design with no clinical or radiographic signs of pulpal or periradicular pathology and pathological wear. All of the primary teeth have their occlusal and proximal contacts.

Exclusion criteria were having one of the following situations; disabilities, pulpitis, non-vital or endodontically treated teeth, profound or chronical periodontitis, deep carious defects(close to pulp, $<1 \mathrm{~mm}$ distance) or pulp capping, heavy occlusal contacts or history of bruxism, systemic disease or severe medical complications, allergic history concerning methacrylate, rampant caries, xerostomia, lack of compliance and language barriers.

After the clinical and bitewing radiographic examination, convenient sample of 33 healthy children between 4 and 9 years of age were selected. Children were asked for their assent after the parents gave written consents. Split mouth design was applied for the study. The children were randomly assigned either right or left halves of their dentition and were treated with local anesthesia and rubber dam isolation by a pediatric dentist. The side, which restoration method was allocated, was assigned by computer-generated randomisation. The advantage of such a split-mouth design over randomising individual patients was the reduction in interparticipant variability (13). Each child was treated by the same operator to avoid behavioral problems.

\section{Interventions}

During the restorative procedure, the operator removed only carious lesions and performed no retention such as undercutting or dovetailing. Occlusal cavities were prepared

Table 1: Restorative Materials

\begin{tabular}{|c|c|c|c|}
\hline Materials & Manufacturer & Composition & Application \\
\hline \multirow[t]{2}{*}{ Vertise flow } & \multirow[t]{2}{*}{ Kerr, Orange, CA, USA } & \multirow[t]{2}{*}{$\begin{array}{l}\text { GPDM, Prepolymerized filler, 1-micron } \\
\text { barium glass filler, nano-sized colloidal } \\
\text { silica, nano-sized Ytterbium fluoride }\end{array}$} & $\begin{array}{l}\text { Apply the first layer of Vertise Flow with } \\
\text { moderate pressure for } 15-20 \text { seconds, light- } \\
\text { cure for } 20 \text { seconds. For A3.5 and Universal } \\
\text { Opaque, cure for } 40 \text { seconds. }\end{array}$ \\
\hline & & & $\begin{array}{l}\text { If necessary, build the restoration } \\
\text { incrementally with Vertise Flow in } 2 \mathrm{~mm} \text { or } \\
\text { less thickness, light-cure for } 20 \text { seconds. } \\
\text { For A3.5 and Universal Opaque, cure for } 40 \\
\text { seconds. }\end{array}$ \\
\hline $\begin{array}{l}\text { Clearfil SE Bond } \\
\text { primer }\end{array}$ & $\begin{array}{l}\text { Kuraray Medical Inc, } \\
\text { Okayama, Japan }\end{array}$ & $\begin{array}{l}\text { MDP, HEMA, dimethacrylate monomer, } \\
\text { water, catalyst }\end{array}$ & $\begin{array}{l}\text { Apply for } 20 \text { seconds and dry thoroughly } \\
\text { with mild air. }\end{array}$ \\
\hline $\begin{array}{l}\text { Clearfil SE Bond } \\
\text { bond }\end{array}$ & $\begin{array}{l}\text { Kuraray Medical Inc, } \\
\text { Okayama, Japan }\end{array}$ & $\begin{array}{l}\text { MDP, HEMA, dimethacrylate monomer, } \\
\text { microfiller, catalyst }\end{array}$ & $\begin{array}{l}\text { Apply after application of primer, air-flow } \\
\text { gently and light-cure for } 10 \text { seconds. }\end{array}$ \\
\hline Filtek Z250 & $\begin{array}{l}\text { 3M ESPE, St Paul, MN, } \\
\text { ABD }\end{array}$ & $\begin{array}{l}\text { BIS-GMA, UDMA and BIS-EMA. Encore- } \\
\text { GMA, UDMA, Encore-EMU, Zirconium/ } \\
\text { Silicon } 60 \% \text { ( } 0.01 \text { to } 3.5 \text { micrometers) }\end{array}$ & $\begin{array}{l}\text { Place Filtek Z250 Restorative in increments. } \\
\text { Light-cure each increment for } 40 \mathrm{sec} \\
\text { (Reference Light-Cure chart for thickness } \\
\text { and cure time.) }\end{array}$ \\
\hline
\end{tabular}


$2 \mathrm{~mm}$ to $4 \mathrm{~mm}$ depth. The dentist prepared the teeth with a 330 bur (KG Sorensen, São Paulo, Brazil) in a high speed hand-piece with water coolant. Afterwards a round carbide bur was used at slow speed in dentin. During the dental cavity preparation, if pulp tissue was exposed or the required cavity size was larger than the study design, the teeth were excluded from the study. Eventually 2 patients were excluded.

All 31 patient received two different types of restorative treatment. A total of 62 occlusal cavities were restored with either a self-adhering flowable composite (VF) or a commercially available self-etch adhesive/composite system (CR) according to manufacturers' instructions. Restorative materials were handled and applied in accordance with the manufacturers' instructions (Table 1).

Figure 1 shows primary tooth occlusal restoration with selfadhering flowable composite.

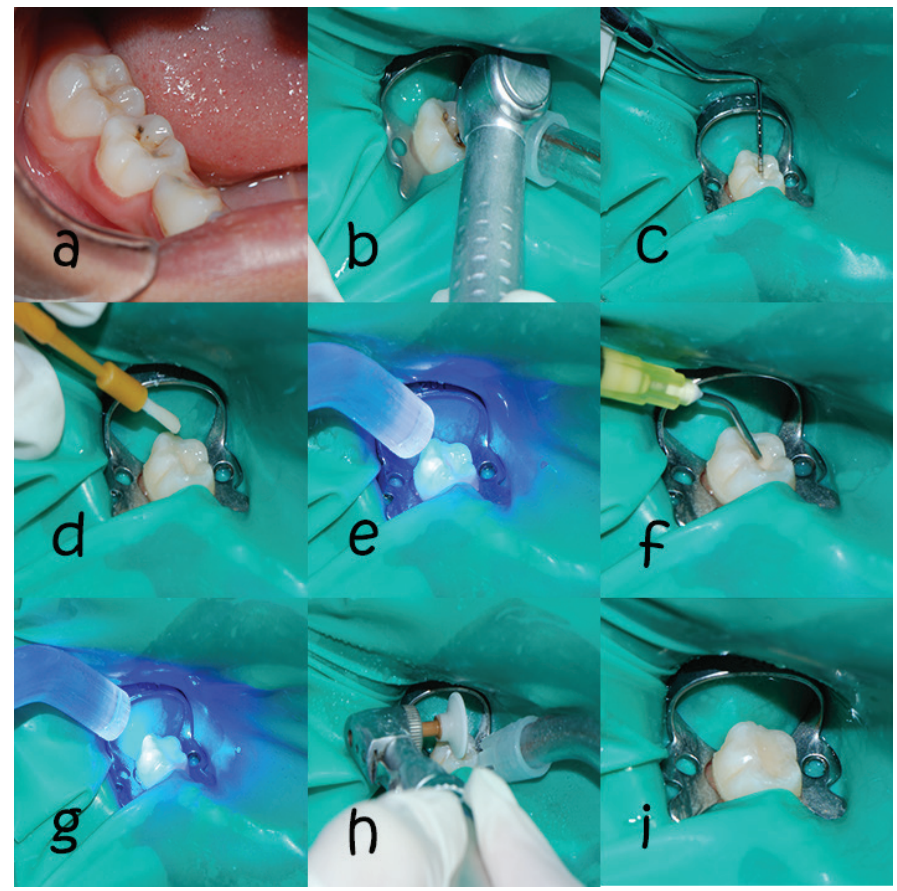

Figure 1. Cavity preparation and the application of the flowable composite resin. a: preoperative, b: cavity preparation, c: prepared cavity, d: first layer replacement and brushing for 20 seconds, e: 20s polymerization, $f$ : second layer placement, $g$ : 20 s polymerization $h$ : finishing and polishing, i: final restoration.

The occlusal relationship was checked with carbon paper (Accufilm II, Parkell, USA) and adjusted with fine granulation burs. Final finishing and polishing procedures were carried out with fine and ultrafine granulation diamond burs (KG Sorensen, Sa o Paulo, Brazil) and finishing was made with a diamond polishing paste (Dentsply, Rio de Janeiro, RJ, Brazil).

\section{Outcomes}

The restorations were clinically evaluated 1 month after restorations, and after 3,6 months and 1 year post-operatively using modified United States Public Health Service (USPHS) criteria by two previously calibrated operators who were different from the treatment applied operator (14). The restorations were re-evaluated by two blind examiners (total weighted kappa ( $\mathrm{k}$ ) between 0.85 and 0.92 for intraexaminer
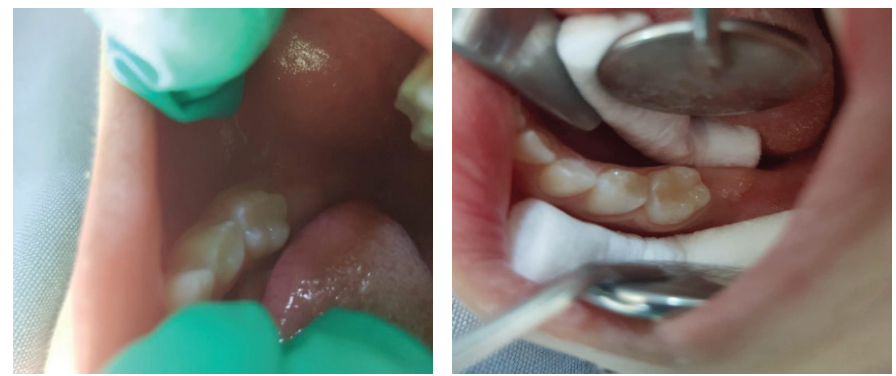

Figure 2. 1 year follow up pictures of the self-adhesive restorations.

and interexaminer agreements). Each restoration was assessed at baseline placement and at the $1^{\text {st }}, 3^{\text {rd }}, 6^{\text {th }}$ months and first year with modified USPHS criteria for retention (R), color match (CM), marginal discoloration (MD), secondary caries (SC), wear (W), marginal adaptation (MA) and postoperative sensitivity (PS). The Alfa and Bravo scores were considered clinically acceptable/ successful of the restorative treatment, while, Charlie scores were clinically unacceptable/ unsuccessful restorative treatment and had to be replaced and excluded from the study. All evaluations were carried out with a dental operating light, mouth mirror, dental explorer and dental floss. Figure 2 shows one year follow up pictures of the self-adhesive restorations.

In addition, each patient received professional cleaning of the teeth and neutral topical fluoride application during the dental appointments. All of the procedures were done by the operators involved in the study.

\section{Statistical Analysis}

The data were processed by SPSS software (12.0, SPSS Inc., Chicago IL, USA). 'Sample size' was calculated 28 at $80 \%$ power, while carrying out a two tailed test at $5 \%$ significance level. 'Sample size' was calculated by G*Power 3.0.10 (15). The kappa statistic was used to measure interrater reliability. The descriptive statistics; the frequency, the mean, the standard deviation and median were calculated for each group. Normality was analyzed using Shapiro-Wilks test. Modified USPHS results were assessed by Mann-Whitney U-test at significance level of $p<.05$.

\section{Results}

\section{Baseline characteristics (patients and teeth)}

31 patients attended the $1^{\text {st }}, 3^{\text {rd }}$ and $6^{\text {th }}$ months recall and 29 patients attended 1 year recall. Lack of retention was not observed in any of the restorations. Split mouth design avoids residual confounding. The age, gender and bio-characteristic of the two groups were identical. Baseline characteristics of the groups; are also included the modified USPHS criteria's of the treatment day results; are given at the Table 2 . The children were between the ages of 4 to 9 , mean 6.67 .

\section{Baseline data and final outcome}

With respect to color match, marginal adaptation, marginal discoloration, secondary caries, postoperative sensitivity no significant differences were found between a self-adhering flowable composite (VF) and a commercially available self- 
Table 2: Baseline characteristics of the groups

\section{N Frequency Mean/median}

\begin{tabular}{|c|c|c|c|c|}
\hline \multicolumn{5}{|l|}{ gender } \\
\hline male & 15 & $\% 48.4$ & & \\
\hline female & 16 & $\% 51.6$ & & \\
\hline \multicolumn{5}{|l|}{ Age } \\
\hline 4 & 2 & $\% 6.5$ & $6.67 / 7$ & \\
\hline 5 & 4 & $\% 12.9$ & & \\
\hline 6 & 7 & $\% 22.6$ & & \\
\hline 7 & 9 & $\% 29.0$ & & \\
\hline 8 & 7 & $\% 22.6$ & & \\
\hline 9 & 2 & $\% 6.5$ & & \\
\hline \multicolumn{5}{|l|}{ group } \\
\hline CR & 31 & $\% 50$ & & \\
\hline VF & 31 & $\% 50$ & & \\
\hline \multicolumn{5}{|l|}{ Modified USPHS criteria } \\
\hline Retention/alpha/bravo/charlie & 62 & $\% 100$ & 1 & Alpha \\
\hline Color Match/alpha/bravo/charlie & 62 & $\% 100$ & 1 & Alpha \\
\hline Marginal Discoloration/alpha/bravo/charlie & 62 & $\% 100$ & 1 & Alpha \\
\hline Secondary Caries/alpha/charlie & 62 & $\% 100$ & 1 & Alpha \\
\hline Wear/alpha/charlie & 62 & $\% 100$ & 1 & Alpha \\
\hline Retention/alpha/charlie & 62 & $\% 100$ & 1 & Alpha \\
\hline Color Match/alpha/charlie & 62 & $\% 100$ & 1 & Alpha \\
\hline
\end{tabular}

Table 3: Modified USPHS scores of $1^{\text {st }}$ and $3^{\text {th }}$ month

1.month

VF

Mean \pm SD (Median)

Retention

$1.00 \pm 0.00(1.00)$

Color Match

$1.03 \pm 0.18(1.00)$

Marginal Discoloration

Secondary Caries

Wear

Marginal Adaptation

Postoperative Sentisivity

Total

$1.00 \pm 0.00(1.00)$

$1.00 \pm 0.00(1.00)$

$1.00 \pm 0.00(1.00)$

$1.00 \pm 0.00(1.00)$

$\begin{array}{cc}\text { Total } & 7.06 \pm 0.25(7)\end{array}$

CR

Mean \pm SD (Median)

$1.03 \pm 0.18(1.00)$

Mean \pm SD (Median)

3. month

Mann whitney $\mathrm{U}$ test for grouping materials VF (self adhering flowable composite) and CR (commercially available self-etch adhesive/ composite system) for the 1. and 3. months; $p<0.05$ is statistically significant

etch adhesive/composite system (CR) after 1 month, 3 months, 6 months and 1 year (Figure 2). Table 3 showed the difference between the groups according to results of first and third month USPHS control. A score called 'total' which was the sum of the modified USPHS scores; were added to the tables. At the end of the $3^{\text {th }}$ month 'Total' scores were also not statistically significant between the groups $(p=0.765)$.

Table 4 shows the $6^{\text {th }}$ month and 1 year results of the VF and CR groups, there were no significant differences between the groups for retention, color match, marginal discoloration, secondary caries, wear, marginal adaptation, postoperative sensitivity and total USPHS criteria.

\section{Discussion}

This study aimed to evaluate the clinical performance of a new self-adhering flowable composite for 1 year using modified USPHS criteria. Based on the findings of 
1. year

\begin{tabular}{|c|c|c|c|c|}
\hline & $\begin{array}{c}\text { VF } \\
\text { Mean } \pm S D \text { (Median) }\end{array}$ & $\begin{array}{c}\text { CR } \\
\text { Mean } \pm \text { SD (Median) }\end{array}$ & $\begin{array}{c}\text { VF } \\
\text { Mean } \pm S D \text { (Median) }\end{array}$ & $\begin{array}{c}\text { CR } \\
\text { Mean } \pm S D \text { (Median) }\end{array}$ \\
\hline Retention & $1.03 \pm 0.18(1.00)$ & $1.00 \pm 0.39(1.00)$ & $1.00 \pm 0.00(1.00)$ & $1.10 \pm 0.49(1.00)$ \\
\hline Color Match & $1.03 \pm 0.18(1.00)$ & $1.00 \pm 0.00(1.00)$ & $1.03 \pm 0.18(1.00)$ & $1.00 \pm 0.00(1.00)$ \\
\hline Marginal Discoloration & $1.06 \pm 0.35(1.00)$ & $1.03 \pm 0.18(1.00)$ & $1.07 \pm 0.37(1.00)$ & $1.10 \pm 0.41(1.00)$ \\
\hline Secondary Caries & $1.03 \pm 0.18(1.00)$ & $1.03 \pm 0.18(1.00)$ & $1.07 \pm 0.25(1.00)$ & $1.03 \pm 0.18(1.00)$ \\
\hline Wear & $1.00 \pm 0.00(1.00)$ & $1.03 \pm 0.18(1.00)$ & $1.00 \pm 0.00(1.00)$ & $1.07 \pm 0.25(1.00)$ \\
\hline Marginal Adaptation & $1.03 \pm 0.18(1.00)$ & $1.06 \pm 0.18(1.00)$ & $1.03 \pm 0.18(1.00)$ & $1.07 \pm 0.25(1.00)$ \\
\hline Postoperative Sensitivity & $1.06 \pm 0.25(1.00)$ & $1.03 \pm 0.18(1.00)$ & $1.07 \pm 0.25(1.00)$ & $1.07 \pm 0.25(1.00)$ \\
\hline Total & $7.26 \pm 0.77(7)$ & $7.29 \pm 0.58(7)$ & $7.28 \pm 0.79(7)$ & $7.31 \pm 0.60(7)$ \\
\hline
\end{tabular}

Mann Whitney $\mathrm{U}$ test for grouping materials VF (self adhering flowable composite) and CR (commercially available self-etch adhesive/ composite system) for the 6 . month and $1^{\text {st }}$ year; $p<0.05$ is statistically significant.

the present study; clinical assessment of self-adhering flowable composite exhibited acceptable clinical results with predominating alpha scores after 1 year. Incorporation of the bonding agent into a flowable composite holds great potential such as; saving chair time and minimizing handling errors. In this study, a commercially self-etch adhesive and a composite resin was used as control group because of its announced gold standard for in vitro studies and its good clinical performance.

The self-adhering flowable composite holds great potential with respect to saving chair time and minimizing handling errors. The advantages for pediatric dentistry are reducing operative procedures, minimizing the technical sensitivity, simultaneous demineralization and resin infiltration as well as in reducing postoperative complaints like pain (16).

The use of flowable restorative systems in dentistry has increased because of their beneficial properties, such as low viscosity, low modulus elasticity and ease of handling (13). For the restoration of cavities in high load bearing areas, the use of flowable composite resins are recommended only for cavity lining but flowable composites has been proposed for the restoration of small-sized cavities, while the occlusal forces are resisted by the residual tooth structure (2).

Various methods were designed for clinical evaluation of restorations $(17,18)$. Among them, modified United States Public Health Service (USPHS) criteria has been used the most widely with various modified forms to determine the clinical performance of dental restorations (14,19-21). In this study modified USPHS criteria was used which is a longestablished method used in clinical trials. In between the two materials there were no difference for the criteria's 'retention', 'color match', 'marginal discoloration,' 'secondary caries', 'wear', 'marginal adaptation' and 'postoperative sensitivity' in the first, third, sixth months and the first year.

There were limited studies about self-adhering flowable composite resin. Pacifici et al. (22) had concluded that occlusal cavities, restored with self-adhering flowable composite resin, provided satisfactory sealing ability despite the relatively low bond strength recorded on enamel and dentin. The results of the study by Tuloglu et al. (23) showed that, the self-adhering flowable composite resin has lower bond strength values than conventional flowable resin composite for both primary and permanent dentin. They suggested that the use of a bonding agent significantly increased the shear bond strength values of self-adhering flowable composite resin to both permanent and primary tooth dentin. Selfadhering flowable composite resin established similar bond strength values as glass ionomer cements on primary dentin (24). Although VF resulted in lower bond strengths values on either dental substrate, better marginal sealing ability was visualized in comparison with all-in-one adhesive systems $(2,25)$. Recent studies showed similar successful results of clinical usage of self-adhesive flowable restorative materials in primary dentition $(26,27)$.

The preservation of primary teeth is important for the management of the developing dentition until normal exfoliation takes place. Restorations of primary teeth are usually performed using composite resin, compomer or glass ionomer and needs to be durable. For the clinical success of composite resin restoration an effective bond between dental materials and tooth substrates is critical (28). Pediatric restorative dentistry is a dynamic area with rapid development of technology and new materials. Among the materials used in the pediatric dental restorations, self-adhering flowable composite resin, with its clinical handling properties and the ability of reducing the time on dental unit, has different advantages during dental treatment.

\section{Conclusion}

Clinical assessment of self-adhering flowable composite exhibited good clinical results with predominating alpha scores after 1 year in this study. The findings of this clinical study suggest that self-adhering flowable composite resin can be used successfully in occlusal cavities of primary teeth. The advantage of the application convenience for children is promising for self-adhered flowable composite materials in pediatric use.

Türkçe Öz: Kendinden adezyonlu akışkan bir kompozitin süt dişlerinde okluzal kavite materyali olarak klinik değerlendirmesi: 1 yıllık sonuçlar. Amaç:Kendinden adezyonlu akışkan kompozitler ayrı bir adeziv olmadan 
diş dokusuna bağlanır ve bond maddesini doğrudan akışkan rezinin içine yerleştirerek restoratif prosedürü kolaylaştırır. Bu çalışmanın amacı, kendinden adezyonlu akıcı bir kompozitin ve konvansiyonel bir kompozit sisteminin klinik performanslarını 12 ay süresince değerlendirmek ve karşılaştırmaktır. Gereç ve Yöntem: Otuz bir hasta (10 erkek, 21 kadın) çalışmaya alındı. Üreticinin talimatlarına göre konvansiyonel bir kompozit veya kendinden adezyonlu bir akışkan kompozit ile toplam 62 okluzal kavite restore edildi. Restorasyonlar işlem sonrası 1 ay ve sonrasında 3 , 6 ve 12. aylarda modifiye USPHS kriterleri ile klinik olarak değerlendirildi. Bulgular: Restorasyonların hiçbirinde retansiyon problemi gözlenmedi. Renk uyumu, marjinal adaptasyon, ikincil çürükler ve yüzey dokusu açısından 12 ay sonra test edilen iki restoratif materyal arasında anlamlı bir fark bulunmadı. Restorasyonların hiçbirinde 12 aylık takipte marjinal renk değişikliği ve anatomik form kaybı olmadı. Restorasyonlar, herhangi bir değerlendirme sırasında işlem sonrası hassasiyet göstermedi. Sonuç: Kendinden adezyonlu akıc kompozitin klinik değerlendirmesi, 12 ay sonra baskın alfa skorları ile iyi sonuçlar vermiștir. Çocuklar için uygulama rahatı̆ı̆ının avantajı, pediatrik kullanımda kendinden adezyonlu akıcı kompozit malzemeler için umut vericidir. Anahtar Kelimeler: Kendinden adezyonlu; restoratif; süt; dişlenme; çocuk; çürük

Ethics Committee Approval: The study protocol and informed consent document was approved by the Çukurova University Ethical Committee (April 4, 2014, study approval number 30).

Informed Consent: Informed consents was provided by the participants' parents.

Peer-review: Externally peer-reviewed.

Author contributions: BAS, IY and MCD designed the study. IY and CD participated in generating the data for the study. BAS and IY participated in gathering the data for the study. IY participated in the analysis of the data. BAS and IY wrote the majority of the original draft of the paper. BAS and IY participated in writing the paper. All authors approved the final version of this paper.

Conflict of Interest: The author had no conflict of interest to declare.

Financial Disclosure: The author declared that this study has received no financial support.

\section{References}

1. Wright JW. The burden and management of dental caries in older children. Pediatr Clin North Am 2018;65(5):955-63. [CrossRef]

2. Vichi A, Margvelashvili M, Goracci C, Papacchini F, Ferrari M. Bonding and sealing ability of a new self-adhering flowable composite resin in class I restorations. Clin Oral Investig 2013;17:1497-1506. [CrossRef]

3. Bayne SC, Thompson JY, Swift EJ, Stamatiades P, Wilkerson M. A characterization of first-generation flowable composites. J Am Dent Assoc 1998;129:567-77. [CrossRef]

4. Helvatjoglu-Antoniades $M$, Papadogiannis $Y$, Lakes RS, Dionysopoulos P, Apadogiannis D. Dynamic and static elastic moduli of packable and flowable composite resins and their developmentafter initial photo curing. Dent Mater 2006;22:4509. [CrossRef]

5. Labella R, Lambrechts P, Van Meerbeek B, Vanherle G. Polymerization shrinkage and elasticity of flowable composites and filled adhesives. Dent Mater 1999;15:128-37. [CrossRef]

6. Leevailoj C, Cochran MA, Matis BA, Moore BK, Platt JA. Microleakage of posterior packable resin composites with and without flowable liners. Oper Dent 2001;26:302-7.

7. Unterbrink GL, Liebenberg $W H$. Flowable resin composites as "filled adhesives": literature review and clinical recommendations. Quintessence Int 1999;30:249-57.

8. Cantekin K, Buyuk SK. Shear bond strength of a new lowshrinkage flowable composite for orthodontic bracket bonding. J Dent Child (Chic) 2014;81:63-6.
9. Peterson J, Rizk M, Hoch M, Wiegand A. Bonding performance of self-adhesive flowable composites to enamel, dentin and a nanohybrid composite. Odontology 2018;106:171-80. [CrossRef]

10. Rainer $\mathrm{H}$, Michael JW, Michael JN. Marginal and internal adaptation of extended class I restorations lined with flowable composites. Journal of Dentistry 2003;31:231-9. [CrossRef]

11. Baroudi K, Rodrigues J. Flowable resin composites: a systematic review and clinical considerations. Journal of Clinical and Diagnostic Research 2015;9:ZE18-ZE24. [CrossRef]

12. Schulz KF, Altman DG, Moher D. CONSORT 2010 statement: Updated guidelines for reporting parallel group randomised trials. Int J Surg 2011;9:672-7. [CrossRef]

13. Zanatta RF, da Silva TM, Esper MALR, Bresciani E, Caneppele TMF, Gonçalves SEP. Guidelines for conducting split-mouth clinical studies in restorative dentistry. Brazilian Dent Sci 2017;20:29. [CrossRef]

14. Bayne SC, Schmalz G. Reprinting the classic article on USPHS evaluation methods for measuring the clinical research performance of restorative materials. Clin Oral Investig 2005;9:209-14. [CrossRef]

15. Faul F, Erdfelder E, Lang AG, Buchner A. G* Power 3: A flexible statistical power analysis program for the social, behavioral, and biomedical sciences. Behav Res Methods 2007;39:175-91. [CrossRef]

16. Fu J, Kakuda S, Pan F, et al. Bonding performance of a newly developed step-less all-in-one system on dentin. Dent Mater 2013;322:203-11. [CrossRef]

17. Corona SA, Borsatto MC, Garcia L, Ramos RP, Palma-Dibb RG. Randomized, controlled trial comparing the retention of a flowable restorative system with a conventional resin sealant: one-year follow up. Int J Paediatr Dent 2005;15:44-50. [CrossRef]

18. Goldberg AJ, Rydinge E, Santucci EA, Racz WB. Clinical evaluation methods for posterior composite restorations. J Dent Res 1984;63:1387-91. [CrossRef]

19. Kim KL, Namgung C, Cho BH. The effect of clinical performance on the survival estimates of direct restorations. Restor Dent Endod 2013;38:11-20. [CrossRef]

20. Vann WF Jr, Barkmeier WW, Mahler DB. Assessing composite resin wear in primary molars: four-year findings. J Dent Res 1988;67:876-9. [CrossRef]

21. Lewis G. In vivo occlusal wear of posterior composite restorations. Oper Dent 1991;16:61-9.

22. Pacifici E, Chazine M, Vichi A, Grandini S, Goracci C, Ferrari $M$. Shear-bond strength of a new self-adhering flowable restorative material to dentin of primary molars. J Clin Pediatr Dent 2013;38:149-54. [CrossRef]

23. Tuloglu N, Sen Tunc E, Ozer S, Bayrak S. Shear bond strength of self-adhering flowable composite on dentin with and without application of an adhesive system. J Appl Biomater Funct Mater 2014;12:97-101. [CrossRef]

24. Pacifici E, Chazine M, Vichi A, Grandini S, Goracci C, Ferrari M. Shear-bond strength of a new self-adhering flowable restorative material to dentin of primary molars. J Clin Pediatr Dent 2013;38:149-54. [CrossRef]

25. Rengo C, Goracci C, Juloski J, et al. Influence of phosphoric acid etching on microleakage of a self-etch adhesive and a selfadhering composite. Aust Dent J 2012;57:220-6. [CrossRef]

26. Dias KR, de Andrade CB, Wait TT, Chamon R, Ammari MM, Soviero VM, Lobo L, de Almeida Neves A, Maia LC, Fonseca-Gonçalves A. Efficacy of sealing occlusal caries with a flowable composite in primary molars: A 2-year randomized controlled clinical trial. J Dent 2018;74:49-55. [CrossRef]

27. Sachdeva P, Goswami M, Singh D. Comparative evaluation of shear bond strength and nanoleakage of conventional and self-adhering flowable composites to primary teeth dentin, Contemp. Clin Dent 2016;7:326. [CrossRef]

28. Carvalho RM, Manso AP, Geraldeli S, Tay FR, Pashley DH. Durability of bonds and clinical success of adhesive restorations. Dental materials 2012;28:72-86. [CrossRef] 